\title{
Heavy Metal Fluxes in Tropical Urban Forest Soil in Abidjan District (Côte d'Ivoire)
}

\author{
B. Emile Bolou-Bi1 ${ }^{*}$, D. Jean Baptiste Ettien1, Thierry Philippe Guety1, Mireille Aïkpa Pitta1, \\ Clarisse Balland-Bolou-Bi ${ }^{2}$
}

${ }^{1}$ Département des Sciences du Sol, de l'Eau et de Géomatériaux, Unité de Formation et Recherche des Sciences de la Terre et des Ressources Minières, Université Félix Houphouët-Boigny, Abidjan, Côte d'Ivoire

${ }^{2}$ Laboratory of Water Environment and Urban Systems (LEESU), UMR-MA 102, University of Paris Est Créteil, Créteil, France

Email: ^emile.bolou@univ-fhb.edu.ci

How to cite this paper: Bolou-Bi, B.E., Ettien, D.J.B., Guety, T.P., Pitta, M.A. and Balland-Bolou-Bi, C. (2021) Heavy Metal Fluxes in Tropical Urban Forest Soil in Abidjan District (Côte d'Ivoire). Journal of Agricultural Chemistry and Environment, 10, 169-183.

https://doi.org/10.4236/jacen.2021.102011

Received: December 31, 2020

Accepted: March 14, 2021

Published: April 14, 2021

Copyright $\odot 2021$ by author(s) and Scientific Research Publishing Inc. This work is licensed under the Creative Commons Attribution International License (CC BY 4.0).

http://creativecommons.org/licenses/by/4.0/

\begin{abstract}
In Western Africa, the growth of cities has led to natural resource pollution, especially air pollution. Urban forests play a key role in filtering atmospheric particles and pollutants through the canopy before reaching the soil. This study aims to quantify heavy metal fluxes in an urban forest in the district of Abidjan in order to assess its role in the protection of natural resources. A monitoring of wet deposition (throughfall and open field rain) and litterfall was carried out for six months in the urban forest of the National Floristic Center located in Abidjan, Côte d'Ivoire. The results show that the soil of this urban forest is a ferralsol type characterized by a sandy-clay texture and a low load of coarse elements. The annual litterfall is estimated to $12.16 \pm 0.71 \mathrm{t} \cdot \mathrm{ha}^{-1} \cdot \mathrm{yr}^{-1}$, similar to other tropical forests. Annual quantities of rain and throughfall are in the range of the rainfall recorded in the district of Abidjan (2013 \pm 152 and 1773 $\pm 51 \mathrm{~mm}$ ). Chemical analyses showed that litter and rainfall contain $\mathrm{Mn}, \mathrm{Zn}$, $\mathrm{Ni}, \mathrm{Cr}, \mathrm{Cd}$ and $\mathrm{Hg}$. Manganese and $\mathrm{Zn}$ are the most abundant elements and $\mathrm{Hg}$ the least abundant in both rainfall and litter. The main source of input of the heavy metals into the urban forest soil is associated with biological recycling through the litter. The litterfall contributes to metal fluxes in soil $10^{9}$ times greater than metal fluxes carry by wet depositions (open field rain and throughfall). However, a detailed study of rainfall showed that the forest canopy constitutes a barrier for the transfer of heavy metal to urban soil. This is indicated by a decrease in heavy metal content from open field rain to throughfall. Consequently, this study recommends the creation and maintenance of urban forests to increase biomass canopy and improve atmospheric air quality for West African cities undergoing constant change and development.
\end{abstract}

\section{Keywords}

Urban Forest, Soil, Heavy Metals, Abidjan, Côte d'Ivoire 


\section{Introduction}

In Sub-Saharan Africa, the populations of large cities have increased considerably during the two last decades. This is the case of Abidjan, the biggest city of Côte d'Ivoire. The district of Abidjan accounts alone 3.7 million inhabitants, about a quarter of the population living in the country. According to projections, the district of Abidjan will have 7 million inhabitants in 2030 [1]. This population growth leads to an increase in urbanized areas against forest areas. This induces an intensification of anthropogenic activities (industry, agriculture, road traffic), with the degradation of the urban environment. This degradation mainly concerns the urban atmosphere through the emission of particles and atmospheric pollutants. These particles and atmospheric pollutants present various risks concerning soil and water pollution into heavy metals [2].

Heavy metals, when present in high proportion above the required thresholds, lead to soil pollution. Some authors thus consider heavy metals as markers of soil anthropisation processes in urban areas [3] [4]. Indeed, urban soils are the receptacle of atmospheric pollution induced by anthropogenic activities. They are systems in perpetual transformation in urbanized areas. In general, soils have been permanently created at a geological scale, whereas they are being degraded at an accelerated rate due to the anthropogenic uses developed in urban areas. According to the World Reference Base for Soil Resources [5], if urban soil is the result of the anthropogenic transformation of natural soil, it is referred to as anthroposol. This soil can also be neoformed according to processes involving technical materials, it will be a technosol. These two types of soil, located in urban areas, are the physical support for industrial, agricultural and/or domestic activities. As such, these soils act as a filter controlling the quality of the groundwater that feeds urban populations [6]. The urban soil effect on water filtering is closely linked to the presence of forest and other green spaces in urban areas. Urban vegetation, in particular urban forests, plays a key role in filtering particles and air pollutants through the canopy [7] [8]. Particles and air pollutants, captured by the canopy, are washed out by rainfall and carried to the soil. To date, very few investigations have been carried out on heavy metal fluxes in tropical urban forest ecosystems. This study therefore aims to quantify heavy metal fluxes in an urban forest in the district of Abidjan. Metals investigated in this study are cadmium $(\mathrm{Cd})$, chromium $(\mathrm{Cr})$, mercury $(\mathrm{Hg})$, nickel $(\mathrm{Ni})$, manganese $(\mathrm{Mn})$ and zinc $(\mathrm{Zn})$.

\section{Materials and Methods}

\subsection{Study Area}

This study was carried out in the urban forest of the National Floristic Center (NFC) resulting in the progressive extension of the botanical garden of Cocody. It is an urban forest located within the Félix Houphouët-Boigny University in the Northeast of Cocody in Abidjan, Côte d'Ivoire. It covers an area of 9.3 ha, including 4.7 ha of arboretum and 3.6 ha of fallow land [9]. The forest is located 
between longitudes N 390800 and 391150 and latitudes E 590950 and 591300 (Figure 1).

\subsection{Soil Morphological Description}

Soil morphological descriptions of NFC forest were done using soil pits located by geographical coordinates (longitude, latitude, altitude) GPS at the top, middle and bottom of a toposequence. The different soil profiles along a toposequence were described following classical method indicating location, vegetation, slope, topographical position, based on the observation of typical criteria for describing soil pits (thickness of the horizon, soil colour, presence or absence of organic matter, soil texture, coarse elements, structure, abundance of roots). Then, the type of horizon is indicated according to soil horizons nomenclature (horizon: A, B or C) as well as the type of soil, determined by using the WRB classification.

\subsection{Sampling of Solution and Litter}

The open field precipitations and throughfall were collected over a six-month period covering the rainy season and a short part of the dry season using rain gauges placed at $1.30 \mathrm{~m}$ above the soil surface. Water sampling was carried out regularly every week or after a rain event in Nalgene ${ }^{\circledR}$ vials. The solutions collected were systematically transferred to the laboratory. Then, a composite sample was prepared using three and five replicates respectively for the open field rain and .throughfall. The composite samples were then filtered using a vacuum filtration system with nylon (Whatman ) filters with a diameter of $47 \mathrm{~mm}$ and a porosity of $0.45 \mu \mathrm{m}$. The filtered samples are then stored at $4^{\circ} \mathrm{C}$ until chemical analysis.

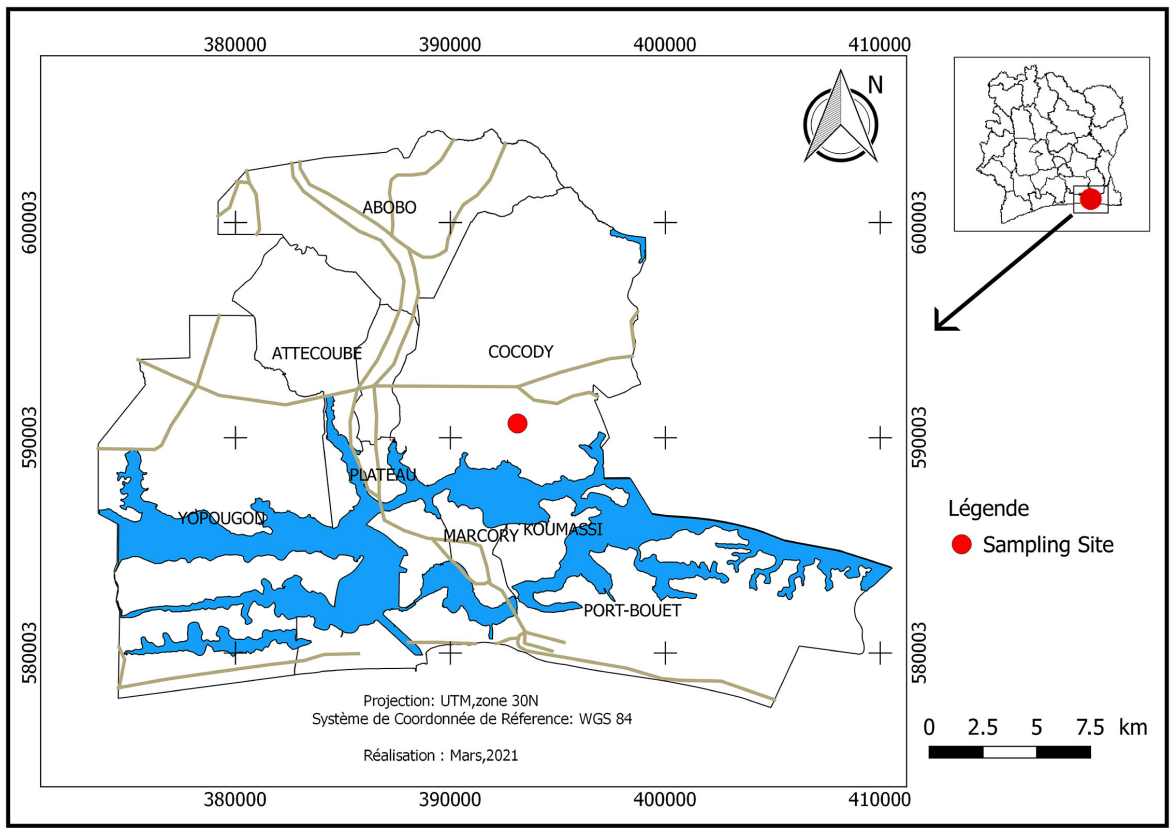

Figure 1. Location of the study zone (Source: Kpangui, 2010). 
Litterfall sampling was carried out biweekly during a period of six months using a one square box placed at a height of $1 \mathrm{~m}$ from the soil floor. The litter was separated into leaves and wood. These various samples are dried in an oven at $70^{\circ} \mathrm{C}$ for 72 hours in order to remove residual moisture. Dried samples were weighed and then a composite sample for each litterfall (leaf and wood) was prepared using individual litterfall collector. These composite samples were crushed, sieved at $25 \mu \mathrm{m}$ to standardize sample grain sizes and stored in the tube until chemical analysis.

\subsection{Chemical Analysis}

Approximately $200 \mathrm{mg}$ of previously dried and crushed materials from plant samples are introduced into a Teflon digestion tube to which $1 \mathrm{ml}$ of hydrogen peroxide (Fulka ${ }^{\circledR}$ Analytical grade) and $3 \mathrm{ml}$ of concentrated nitric acid (Aristar ${ }^{\circledR}$ PLUS, trace metal grade) are added. This set is left at room temperature for 24 hours. The digestion tube is placed on a hot plate at $90^{\circ} \mathrm{C}$ for one night. The resulting mineralized material is evaporated to dryness, then the residue is added to $1 \mathrm{ml}$ of concentrated hydrochloric acid (Supelco ${ }^{\circledR}$ Suprapur ${ }^{\circledR}$ grade) and heated to $75^{\circ} \mathrm{C}$. After cooling, the solution is filtered into vials and the volume of the solutions is adjusted to $50 \mathrm{ml}$. The solutions are then transferred to tubes that have been rinsed with distilled water acidified to $1 \%$ for the determination of heavy metals. The solution samples are acidified with a $1 \% \mathrm{HCl}$ solution to be in the same matrix as soil and plant samples. These samples are then transferred to tubes previously rinsed with distilled water acidified to $1 \%$ for the determination of heavy metals. The solutions or mineralized plant samples were analyzed ( $\mathrm{Cd}, \mathrm{Cr} \mathrm{Mn}, \mathrm{Ni}$ and $\mathrm{Zn}$ ) by inductively coupled plasma mass spectrometry (Va$\operatorname{rian}^{\circledR}$ ) based at INRAe in Nancy (France). The validation of the analytical results is based on the analysis of internal reference samples. These references are introduced at a rate of 1 per 10 samples in the different analysis series. The tests of accuracy, repeatability $(n=3)$ and reproducibility $(n=3)$ carried out on reference samples showed that the results were satisfactory with coefficients of variation less than $5 \%$.

Total mercury was determined by the AMA $254^{\circledR}$ (Automatic Mercury Analyser) based at the LEESU of the University of Paris Est-Créteil, using the thermal decomposition method with gold amalgamation by Atomic Absorption Spectrometry (AAS). This device is specially designed for the direct quantification of low quantity $\mathrm{Hg}$ in solid or liquid samples, as it is equipped with a high-capacity platform and a high-sensitivity cell. This cell allows having a theoretical detection limit of $0.003 \mathrm{ng}$ and a theoretical quantitation limit of $0.01 \mathrm{ng}$. A known weight or volume of sample is dried and thermally decomposed; and the decomposition products of the sample are directed using oxygen flow into the second part of the catalyst tube containing the amalgam for selective $\mathrm{Hg}$ scavenging which is then quantified [10]. The samples are analyzed three times to meet the criteria of the method, i.e. RSD $<15 \%$ for liquid samples and RSD $<$ $5 \%$ for solid samples. 


\subsection{Statistical Processing of Data}

The statistical processing of the data has been done with XLSTAT v. 2017. Normality tests were performed on the data, and then parametric tests were performed to compare the means and variances of the different data series.

\section{Results and Discussion}

\subsection{Morpho-Pedological Characteristics of Soils}

The soils observed in our study are ferralsols according to the WRB classification. The detailed description of the soil profiles is shown in Figure 2 (A, B and C). Briefly, the three soils profile show that in the upper horizon $(0-3 \mathrm{~cm})$ structure of litterfall from vegetation are still recognizable. Gradual transition with \pm regular limit allows to observed dark brown 7.5 YR 3/2 horizon (3 - 10 $\mathrm{cm}$ ) enriched in humus bearing with coarse elements $<1 \%$ and characterized by sandy texture (fine to medium sands with $<2 \%$ of clay). Numerous subhorizontal and subvertical roots are observed in this horizon with subangular structure and good drainage 1.3. Then, the following horizon $(9-30 \mathrm{~cm})$ is also dark brown 7.5 YR 3/2, humus-bearing but with $1 \%$ coarse elements and display sandy texture (fine and medium sands $5 \%-7 \%$ clay) and good drainage 1.4. From about $30 \mathrm{~cm}$, dark brown 7.5 YR $3 / 3$ horizon appear with sandy-clay texture (fine and medium sands $8 \%-10 \%$ clay) and general structure is subangular polyhedral with a tendency to lumpiness and drainage of 1.5. This middle soil horizon is followed by a transitional brown horizon 7.5 YR 4/4 with a coarse element content $<1 \%$, sandy-clay texture ( $10 \%-15 \%$ clay), subangular polyhedral structure and few subhorizontal roots. At least, a deeper intense brown horizon is observed with a coarse element content $<1 \%$, sandy-clay texture (fine sands, $15 \%-20 \%$ clay) with drainage 1.7 . The difference between these soil profiles appears in the deepest horizon. For the mid-slope soil, horizons are mainly yellow ochre 7.5 YR4/4 or intense ochre horizon 7.5YR 5/ while in the downslope soils, horizons are reddish yellow-brown 7.5 YR 5/4 and 7.5YR 6/8 with mainly subangular polyhedral structure.

\subsection{Litterfall Restitution Heavy Metal to Soil}

\subsubsection{Annual Litterfall Production}

The annual litterfall production in NFC forest was estimated to $167.64 \pm 60.27$ $\mathrm{g} \cdot \mathrm{m}^{-2}$ and $49.60 \pm 27.02 \mathrm{~g} \cdot \mathrm{m}^{-2}$ for leaves and wood, respectively, representing $77 \%$ and $23 \%$ of the respective contribution to the overall litterfall. The wood litter production does not show systematic variation from top to bottom, while the production of leaf litter increases by $145 \%$ from top to bottom (Figure 3 ), due to variability in vegetation density on the site [11].

The annual litterfall production in the overall NFC forest area is estimated to $12.16 \pm 0.71 \mathrm{t} \cdot \mathrm{ha}^{-1} \cdot \mathrm{yr}^{-1}$. This estimate of litterfall in this urban forest falls in the range of litterfall values varying from 7 to $15 \mathrm{t} \cdot \mathrm{ha}^{-1} \cdot \mathrm{yr}^{-1}$ in tropical forests. More specifically, litter production in this study is comparable to estimated litterfall at 


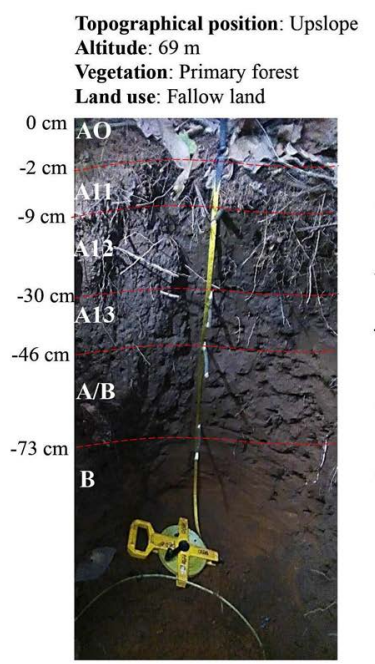

A. Ferralsol (Humic Dystric Arenic)
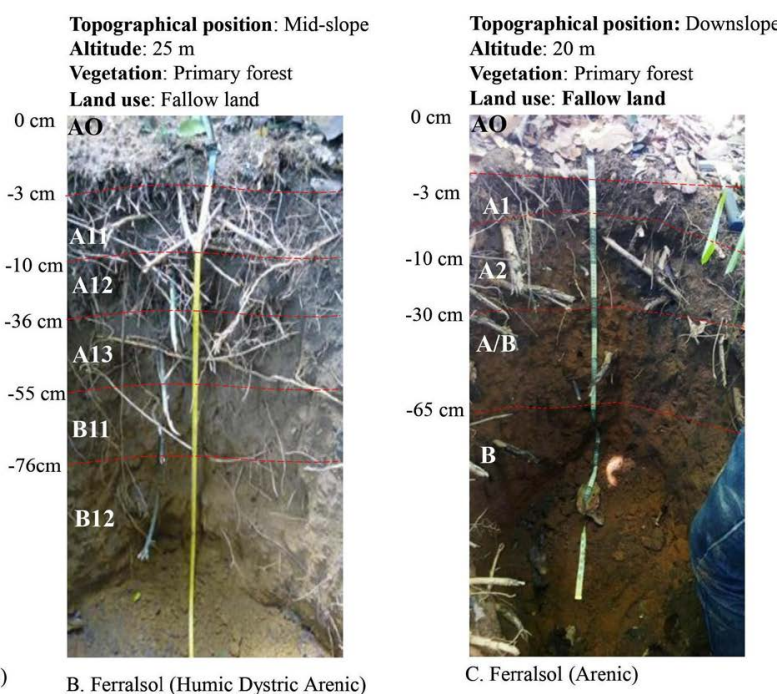

Figure 2. Soil profiles described along a toposequence in the urban forest of the National Cocody Floristic Centre.

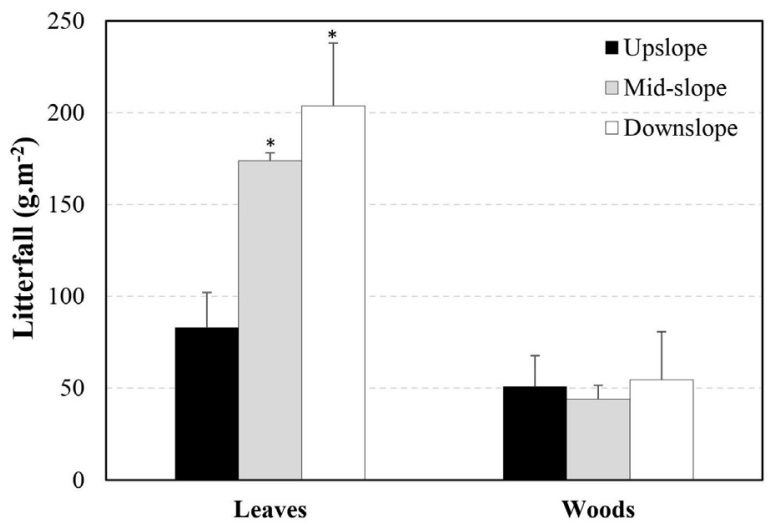

Figure 3. Variability of litter (leaf and wood) according to topographic positions, the symbol ${ }^{*}$ indicates that the values are significantly different at $\mathrm{p}<0.05$.

$11.01 \pm 1.9 \mathrm{t} \cdot \mathrm{ha}^{-1} \cdot \mathrm{yr}^{-1}$ and $9.33 \pm 0.81 \mathrm{t} \cdot \mathrm{ha}^{-1} \cdot \mathrm{yr}^{-1}$ respectively in primary forests of Banco and Grand Yapo located in the Abidjan district [11]. Compared to other urban tropical forests, litterfall is still similar to those estimated at $12 \pm 0.3$ and $9.32 \pm 0.1 \mathrm{t} \cdot \mathrm{ha}^{-1} \cdot \mathrm{yr}^{-1}$ in literature [12] [13] in Nigeria, and at $11 \pm 0.36 \mathrm{t} \cdot \mathrm{ha}^{-1} \cdot \mathrm{yr}^{-1}$ (compiled data) in Ghana [14] [15] [16].

The NFC forest ecosystem appears to be just as productive as other urban tropical forests for the same covered area. However, some studies on tropical forests in West Africa report lower litter production of 1.5 to $3.8 \mathrm{t} \cdot \mathrm{ha}^{-1} \cdot \mathrm{yr}^{-1}$. Similarly, some authors estimate litterfall at $2.8 \mathrm{t} \cdot \mathrm{ha}^{-1} \cdot \mathrm{yr}^{-1}$ for stands in Latin America. This variability in litterfall in tropical forests could be associated with the forest tree species and forest type [17] [18]. In comparison with coniferous and deciduous forests in temperate regions, for which a high variability in litterfall is observed in some studies [19], it is possible to distinguish in tropical areas between forests with deciduous (semi-deciduous) species and forests with ever- 
green species (evergreen forests). Semi-deciduous or deciduous forests show a significant seasonal variation in litter production [20]. Whereas evergreen forests produce large amounts of litter continuously throughout the year [20] [21]. It is conceivable that in this study, the forest produces a similar amount of litter as the Banco forest because they are both evergreen forests [11]. The leaf fraction constitutes more than $77 \%$ of the total litterfall. This result is comparable to the estimated average leaf percentage of $75 \%$ in tropical forests [12] [13]. The last quarter of the litter production is represented by the fraction of lignified organs (e.g. wood). In tropical forests, seeds are rare in the litter, which is evidence of the rare fruiting of trees in this forest [11].

\subsubsection{Heavy Metal Fluxes to Soil through Litterfall}

Table 1 summarizes statistical data for various data of heavy metal contents in litterfall. The analysis results show that the mean values of the total metal contents in both samples follow a decreasing order $\mathrm{Mn} \gg \mathrm{Zn}>\mathrm{Ni}>\mathrm{Cr}>\mathrm{Cd} \gg$ Hg.

Detailed analysis indicates that, with exception of $\mathrm{Hg}$, there is no significant difference between heavy metal content in leaf and wood litterfall (Figure 4(A)). However, when comparing leaf and wood contents, two groups can be statistically distinguished. $\mathrm{Cd}$ and $\mathrm{Zn}$ are enriched in wood by $36 \%$ and $21 \%$ respectively, while the other metals $(\mathrm{Cr}, \mathrm{Ni}, \mathrm{Mn}, \mathrm{Hg})$ are concentrated in leaf litterfall by $23 \%, 11 \%, 41 \%$ and $76 \%$ respectively.

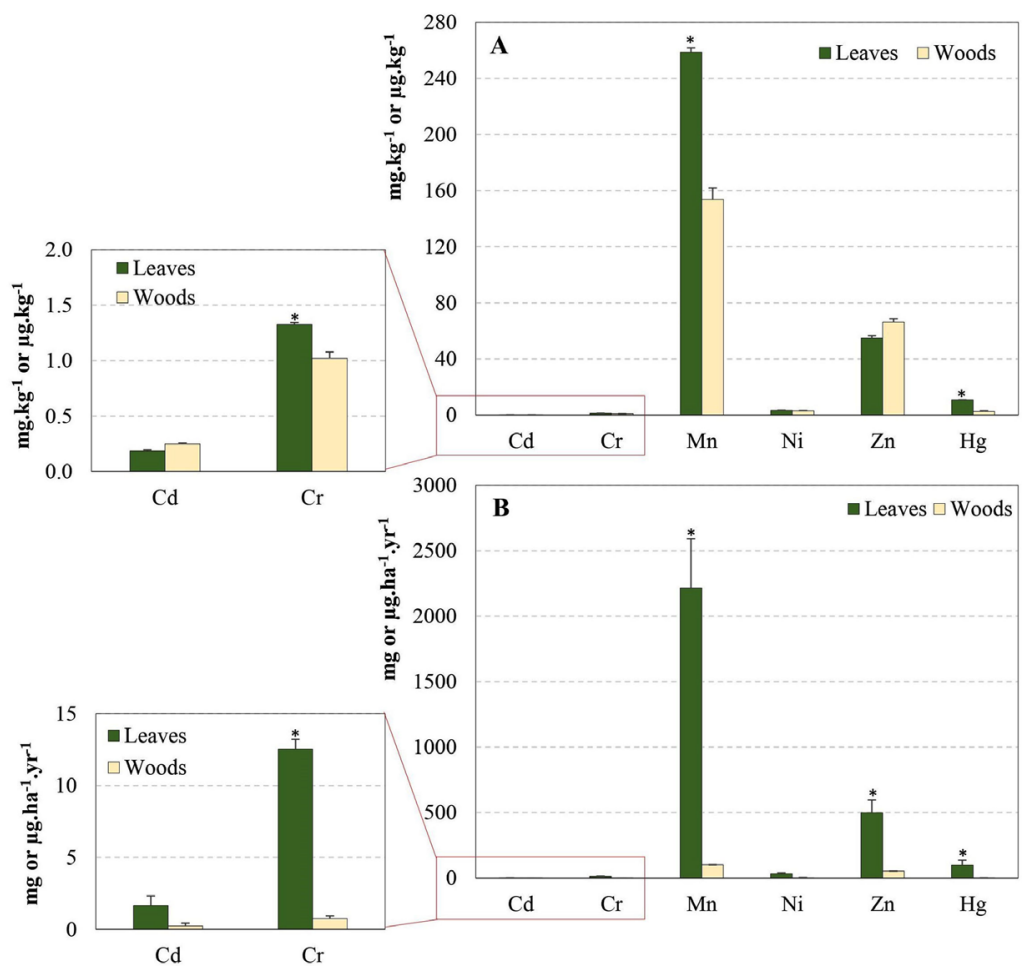

Figure 4. Content (A) in litterfall and annual flux (B) of heavy metals in the urban forest of the National Cocody Floristic Centre, the symbol * indicates that the values are significantly different at $\mathrm{p}<0.05$. 
Table 1. Statistical distribution of ETM data analyzed from 15 observations of collected litterfall (leaves and wood).

\begin{tabular}{|c|c|c|c|c|c|c|c|c|c|c|c|c|}
\hline \multicolumn{7}{|c|}{ Leaves } & \multicolumn{6}{|c|}{ Wood } \\
\hline & $\mathrm{Cd}$ & $\mathrm{Cr}$ & $\mathrm{Mn}$ & Nor & $\mathrm{Zn}$ & $\mathrm{Hg}$ & $\mathrm{Cd}$ & $\mathrm{Cr}$ & $\mathrm{Mn}$ & Nor & $\mathrm{Zn}$ & $\mathrm{Hg}$ \\
\hline & & & $\mathrm{mg} \cdot \mathrm{kg}^{-1}$ & & & $\mu \mathrm{g} \cdot \mathrm{kg}^{-1}$ & & & $\mathrm{mg} \cdot \mathrm{kg}^{-1}$ & & & $\mu \mathrm{g} \cdot \mathrm{kg}^{-1}$ \\
\hline Maximum & 0.27 & 1.94 & 395.49 & 4.69 & 89.98 & 15.91 & 0.52 & 1.63 & 416.29 & 8.17 & 122.83 & 4.55 \\
\hline 3rd quartile & 0.22 & 1.63 & 331.21 & 3.91 & 65.93 & 11.82 & 0.30 & 1.32 & 175.08 & 3.74 & 79.11 & 3.34 \\
\hline Median & 0.17 & 1.14 & 270.43 & 3.37 & 48.32 & 10.17 & 0.23 & 1.00 & 146.07 & 2.78 & 63.62 & 2.47 \\
\hline IQR & 0.06 & 0.56 & 148.17 & 1.06 & 23.80 & 2.66 & 0.15 & 0.53 & 91.49 & 1.63 & 31.99 & 1.30 \\
\hline 1st quartile & 0.16 & 1.07 & 183.04 & 2.85 & 42.13 & 9.16 & 0.15 & 0.79 & 83.59 & 2.11 & 47.12 & 2.04 \\
\hline Minimum & 0.12 & 0.91 & 118.46 & 2.42 & 37.90 & 7.78 & 0.10 & 0.25 & 1.40 & 0.59 & 30.65 & 1.29 \\
\hline Average & 0.18 & 1.33 & 258.83 & 3.41 & 54.96 & 10.79 & 0.25 & 1.02 & 153.71 & 3.03 & 66.49 & 2.59 \\
\hline Standard Deviation & 0.01 & 0.06 & 8.26 & 0.15 & 2.20 & 0.48 & 0.01 & 0.02 & 3.01 & 0.09 & 1.73 & 0.05 \\
\hline
\end{tabular}

Estimating the annual fluxes of heavy metals reaching soil through the litterfall also indicates the following sequence $\mathrm{F}_{\mathrm{Mn}} \gg \mathrm{F}_{\mathrm{Zn}}>\mathrm{F}_{\mathrm{Ni}}>\mathrm{F}_{\mathrm{Cr}}>\mathrm{F}_{\mathrm{Cd}} \gg \mathrm{F}_{\mathrm{Hg}}$ (Figure 4(B)). The results show that heavy metal fluxes through leaf litterfall are higher than fluxes through wood litterfall. Leaf litterfall accounts for between $87 \%$ and $98 \%$ of the metal flux to soil. These results are assumed to be the first data estimating metal fluxes in tropical urban forests. Results of this study are similar to those obtained forests in temperate regions [22] [23] [24]. Excepted Mn, high metal contents in urban forest litterfall could be explained by its importance in anthropogenic activities. Metals extracted from continental crust are refined and converted into various chemical forms for use in many human activities. Thus, anthropogenic activities are now involved in the biogeochemical cycles of metals [25] [26]. The specific character of zinc is used in various anthropogenic activities such as steel coating processes, the manufacture of automotive equipment and household appliances. It is also used in building (roofing of Zn-based alloy), all rubber-based products and in fertilizers. Thus, all these industrial activities have led to an anthropogenic transfer of $\mathrm{Zn}$ from natural resources to the atmosphere, resulting in an increase in the concentrations of zinc in the atmosphere compared to $\mathrm{Ni}, \mathrm{Cd}, \mathrm{Cr}$ and $\mathrm{Hg}$. Atmospheric $\mathrm{Zn}$ is contained in atmospheric aerosols fall to urban soils either by dry deposition or during rainy episodes. Urban forest canopy reduces this metal deposition to soil [27], because aerosols are deposited on leaves before their transfer to heavy metals to soil [28]. Like $\mathrm{Zn}, \mathrm{Ni}$ is also frequent in anthropogenic activities and it is conceivable that these two elements have the highest fluxes to the soil via the litter in comparison with other heavy metals. For these others metals, their levels in the urban atmosphere are controlled by natural sources (marine aerosols and biogenetic processes) [29].

\subsection{Contribution of Heavy Metals by Rainfall}

In this study, data for open field precipitation and throughfall indicate annual 
mean values of $2013 \pm 152 \mathrm{~mm}$ and $1773 \pm 51 \mathrm{~mm}$, respectively [30]. The $\mathrm{pH}$ values of open field precipitation range from 6.34 to 6.96 with a mean $\mathrm{pH}$ value of $6.55 \pm 0.18$. The $\mathrm{pH}$ values of throughfall vary from 6.45 to 7.83 with an average $\mathrm{pH}$ value of $7.01 \pm 0.31$. Although the average $\mathrm{pH}$ value of throughfall is 0.5 $\mathrm{pH}$ units higher than open field precipitation (Figure 5), this difference is not statistically significant. These $\mathrm{pH}$ values indicate that rainfalls could be considered neutral because the $\mathrm{pH}$ of rainfall is qualified as acidic when the $\mathrm{pH}$ value $\leq 4.8$. The $\mathrm{pH}$ of the rainfall is in agreement with the values measured in Côte d'Ivoire indicating an average $\mathrm{pH}$ of 6.7 in open field precipitations [31]. However, these obtained $\mathrm{pH}$ values are higher than the $\mathrm{pH}$ of precipitations in highly industrialized urban areas with pH values below 6 [23] [32] [33].

The neutrality of rainfall in our study area could be explained by the low emission of carbon dioxide and/or sulphur dioxide into the atmosphere through anthropogenic activities (industrial and road traffic) in the district of Abidjan. The $\mathrm{pH}$ of the rainwater would be mainly controlled by the dissolution of carbon dioxide and sulphur dioxide in the water drops. Moreover, the proximity of the district of Abidjan to the ocean helps to neutralise the water by adding marine aerosols with a $\mathrm{pH}$ of about 8.2 [34]. A comparison of rainfall with the composition of the ocean shows that this rainfall follows the dilution line of the ocean (Figure 6), suggesting a strong contribution of ocean aerosols to rainfall due to the proximity of the District of Abidjan to the Atlantic Ocean. The slight increase in $\mathrm{pH}$ values under-covered precipitation is classically observed in various studies on forest ecosystems. It is due to a contribution of bases in incident rainwater following exchanges between elements present in plant tissues and those contained in incident rainfall and/or to leaching of atmospheric particles from the foliage [35] [36].

Statistical data on heavy metal compositions of precipitations are presented in Table 2. Zinc and Mn are the most abundant elements in both open field precipitations and throughfall.

Table 2. Statistical distribution of ETM data analyzed from 32 observations of open field precipitations and throughfall.

\begin{tabular}{|c|c|c|c|c|c|c|c|c|c|c|c|c|}
\hline \multicolumn{7}{|c|}{ Open field precipitations } & \multicolumn{6}{|c|}{ Throughfall } \\
\hline & $\mathrm{Cd}$ & $\mathrm{Cr}$ & $\mathrm{Mn}$ & Nor & $\mathrm{Zn}$ & $\mathrm{Hg}$ & $\mathrm{Cd}$ & $\mathrm{Cr}$ & $\mathrm{Mn}$ & Nor & $\mathrm{Zn}$ & $\mathrm{Hg}$ \\
\hline & & & $\mu \mathrm{g} \cdot \mathrm{l}^{-1}$ & & & $\mathrm{ng} \cdot \mathrm{l}^{-1}$ & & & $\mu \mathrm{g} \cdot \mathrm{l}^{-1}$ & & & $\mathrm{ng} \cdot \mathrm{l}^{-1}$ \\
\hline Maximum & 6.47 & 3.94 & 21.37 & 8.66 & 97.88 & 41.70 & 1.07 & 4.99 & 155.49 & 11.65 & 28.93 & 18.20 \\
\hline 3rd quartile & 1.47 & 3.62 & 20.93 & 8.16 & 40.96 & 23.15 & 0.98 & 3.85 & 48.38 & 8.10 & 14.56 & 9.55 \\
\hline Median & 1.18 & 3.57 & 20.61 & 7.92 & 27.40 & 18.90 & 0.95 & 3.66 & 30.25 & 7.77 & 13.15 & 6.20 \\
\hline IQR & 0.39 & 0.10 & 0.98 & 0.83 & 23.48 & 10.24 & 0.06 & 0.45 & 26.27 & 0.71 & 3.87 & 5.89 \\
\hline 1st quartile & 1.08 & 3.52 & 19.95 & 7.33 & 17.48 & 12.91 & 0.92 & 3.40 & 22.11 & 7.39 & 10.69 & 3.66 \\
\hline Minimum & 0.98 & 3.41 & 18.36 & 6.86 & 10.54 & 11.63 & 0.78 & 3.03 & 18.16 & 6.60 & 2.61 & 1.43 \\
\hline Average & 1.82 & 3.59 & 20.35 & 7.78 & 35.07 & 20.69 & 0.94 & 3.70 & 41.36 & 8.00 & 13.54 & 7.51 \\
\hline Standard Deviation & 0.01 & 0.02 & 0.13 & 0.04 & 0.59 & 0.01 & 0.00 & 0.00 & 0.02 & 0.00 & 0.01 & 0.00 \\
\hline
\end{tabular}




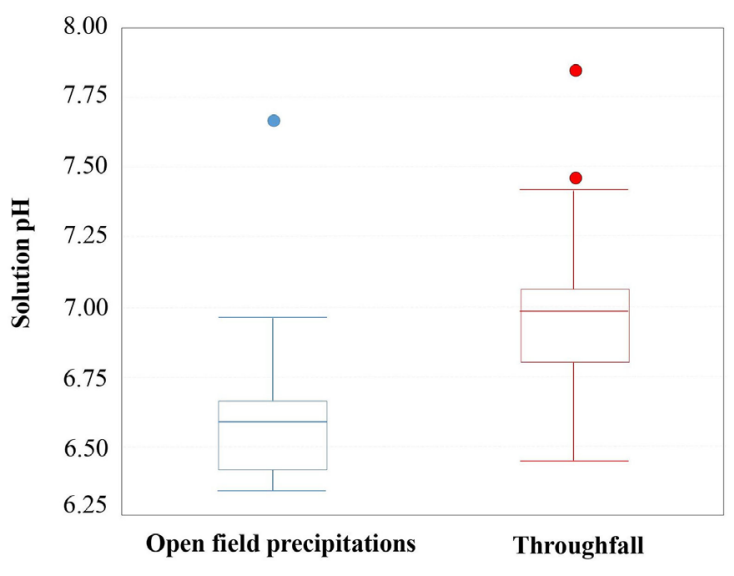

Figure 5. Comparison and statistical distributions of $\mathrm{pH}$ of open field precipitations and throughfall in the urban forest of the National Floristic Centre.

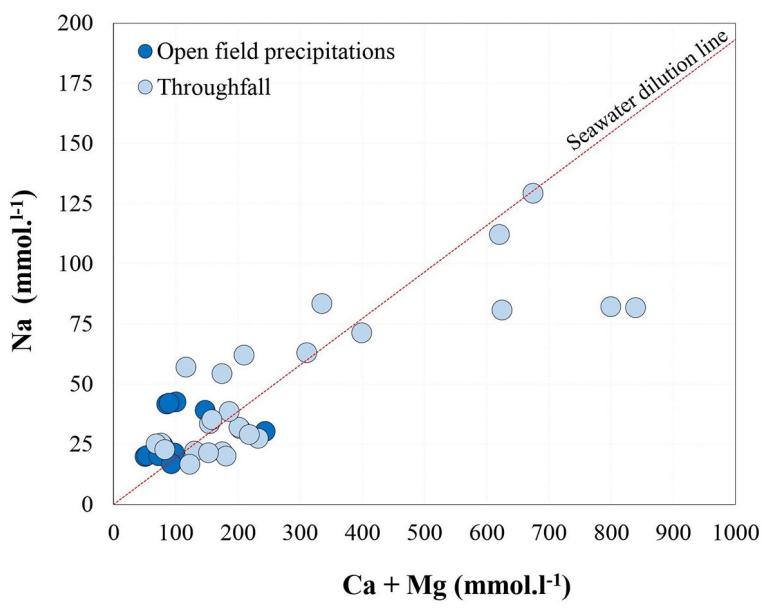

Figure 6. Comparison of open field precipitations and throughfall sample composition to the seawater dilution line using major cations ( $\mathrm{Na}, \mathrm{Ca}$ and $\mathrm{Mg}$ ).

The sequence of heavy metals in these precipitation events follows the same pattern as litterfall. Excepted Mn, heavy metal contents open field precipitations appear to be higher than those in throughfall. However, this difference between these element averages is not significant (Figure 7(A)). Estimating the annual fluxes of heavy metals reaching soil through precipitations indicates a similar sequence to litterfall in open field precipitations, as $\mathrm{F}_{\mathrm{Mn}}>\mathrm{F}_{\mathrm{Zn}}>\mathrm{F}_{\mathrm{Ni}}>\mathrm{F}_{\mathrm{Cr}}>\mathrm{F}_{\mathrm{Cd}}>$ $\mathrm{F}_{\mathrm{Hg}}$ (Figure 7(B)).

The comparison of various precipitation shows that $\mathrm{Mn}$ fluxes reaching soil is dominated by throughfall by contrast to other metal fluxes, which are higher in open field precipitation. The fluxes of heavy metal to soil through open field precipitations are respectively $94 \%, 13 \%, 13 \%, 318 \%$ and $217 \%$ higher for Cd, $\mathrm{Cr}$, Ni $\mathrm{Zn}$ and $\mathrm{Hg}$ compared to metal fluxes through throughfall. On the other hand, the flux of $\mathrm{Mn}$ is $33 \%$ lower than its quantity in throughfall. These results suggest that the forest cover in interaction with atmospheric inputs induces a modification of the chemical composition of rainfall-leachate under forest cover as indicated in several studies in forest ecosystems on base cations $(\mathrm{K}, \mathrm{Ca}$, 
$\mathrm{Mg} \mathrm{...)} \mathrm{[36]} \mathrm{[37]} \mathrm{[38].} \mathrm{Rainfall} \mathrm{is} \mathrm{the} \mathrm{signal} \mathrm{for} \mathrm{atmospheric} \mathrm{inputs} \mathrm{into} \mathrm{a} \mathrm{forest}$ catchment area [39]. Classically, the chemical composition of throughfall is different to open field precipitation [40]. This difference is due to a modification of the chemical composition of open field rain by washing of the canopy leading to dry deposits and mineral salts accumulated and/or partially evaporated on the forest canopy [41] [42]. Leaves excrete protons and low organic acids, which dissolve the dry deposits and then absorb these nutrients through the stomata [43]. Thus, some authors rather suggest a potential dissolution of the particles by the exudation of organic molecules through the canopy [44]. In this case, the chemical composition of the throughfall becomes enriched in metals [23] and could therefore shift slightly from the dilution line of marine aerosols, as suggested by the shift in throughfall samples. This is the case for Mn, where the flux via throughfall is greater than fluxes through open field precipitation, unlike the other heavy metals ( $\mathrm{Cd}, \mathrm{Cr}, \mathrm{Ni}, \mathrm{Zn}$ and $\mathrm{Hg}$ ). The fluxes of these metals decrease under the vegetation canopy. Some authors previously observed the decrease in fluxes of these metals in throughfall [45]. Results would therefore indicate that the canopy participates in the retention of these elements through a direct interaction between rainfall and the canopy. Nickel, $\mathrm{Zn}$ and $\mathrm{Cr}$, for example, are microelements and could be assimilated by the vegetation during this interaction [46] [47]. On the other hand, $\mathrm{Cd}$ and $\mathrm{Hg}$ have no known biological role. Consequently, their fluxes decrease under the forest canopy could be attributed to speciation in small organic complexes that would fix it in the plant [23].

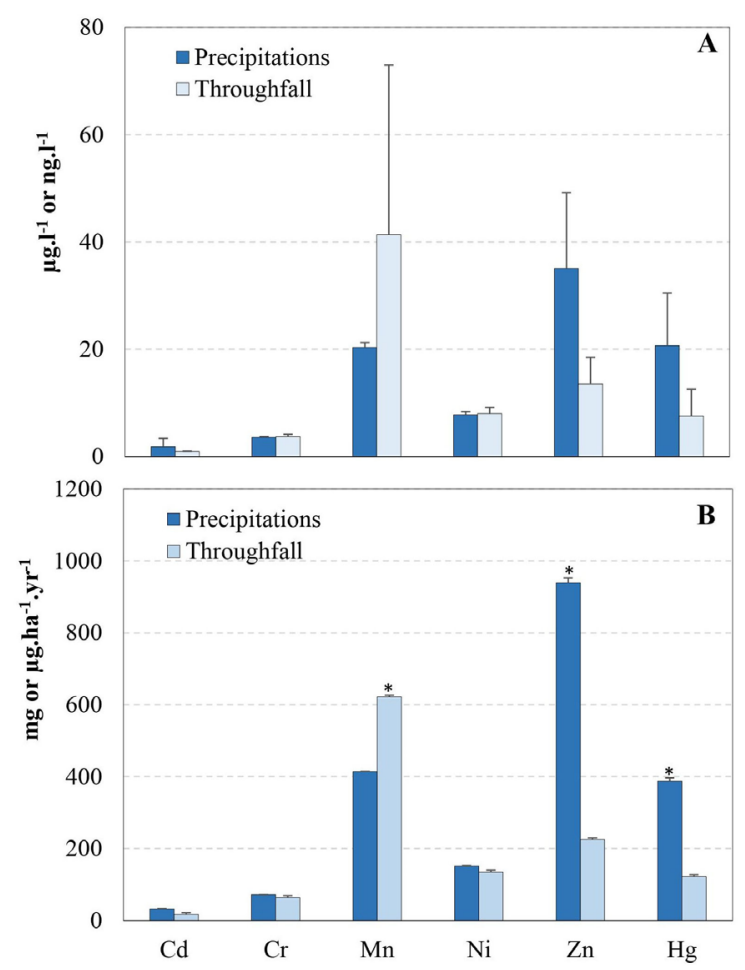

Figure 7. Content (A) and annual flux (B) to soil of heavy metal in open field precipitations and throughfall samples collected in the urban forest of the National Cocody Floristic Centre, the symbol ${ }^{*}$ indicates that the values are significantly different at $\mathrm{p}<0.05$. 


\section{Conclusion}

This study shows that the urban forest is developed on a ferralsol no intensively anthropized. The soils generally have a sandy-clay texture with a low load of coarse elements. The litter collected showed that this urban forest produces a high amount of litterfall, similar in quantity and comparable to other tropical forests. Precipitations (over and under canopy) are in the range of that known in Abidjan district. Chemical analyses have shown that both litter and rainfall contain trace metals. Manganese and $\mathrm{Zn}$ are the most abundant elements and $\mathrm{Hg}$ the least abundant in all samples. The main source of input of the studied heavy metals into the soil of this urban forest is associated with biological recycling through the litter. In fact, litter introduces into the soil flows heavy metals that are $10^{9}$ times greater than fluxes brought by precipitations. Detailed study of precipitations showed that the forest canopy constitutes a barrier for the transfer of trace metals to the soil. This is indicated by a decrease in heavy metal content from open field precipitation to throughfall. However, as litter brings high concentrations of trace metal to the soil, it would be interesting to analyze soil solutions and evaluate the litterfall degradation processes in order to assess the role of urban forest soils in the dynamics of trace metal to water reserves. In any case, this study allows inviting city managers to create urban forests in order to increase the canopy and improve atmospheric air quality in West African cities.

\section{Acknowledgements}

We are particularly grateful to Benoît POLLIER of INRAe at Nancy Center and Vanessa ALPHONSE of LEESU at Créteil University for the analytical support of this work. The authors wish to extend their appreciation to the associate editor and reviewers for their constructive comments about this manuscript.

\section{Conflicts of Interest}

The authors declare no conflicts of interest regarding the publication of this paper.

\section{References}

[1] Guengant, J.P. (2011) How to Benefit from the Demographic Dividend? Demography at the Centre of Development Trajectories in WAEMU Countries as Well as in Guinea, Ghana, Mauritania and Nigeria Paris, Agence Française de Développement. http://www.afd.fr/jahia/Jahia/home/publications/Publicationsthematiques-geograp hiques/conference-ouagadougou

[2] Branchu, P., Badin, A.L., Bechet, B., Eisenlohr, L., Le Priol, T., Marseille, F. and Trielli, E. (2013) Road Pollution and the Local Environment. VertigO-The Electronic Journal of Environmental Sciences, Special Issue No. 15.

[3] Bur, T. (2008) Anthropic Impact on Metallic Trace Elements in Agricultural Soils in Midi-Pyrénées. Implications in Terms of Limits and Critical Loads, $\mathrm{PhD}$ Thesis, University of Toulouse, Toulouse, $399 \mathrm{p}$.

[4] Varrault, G. (2011) Les contaminants dans les milieux récepteurs sous forte pression urbaine. Dissertation for the Habilitation à Diriger des Recherches, Université Par- 
is-Est, Marne-la-Vallée, 89 p.

[5] IUSS Working Group WRB (2007) World Reference Base for Soil Resource 2006. World Soil Resources Reports No. 103, Food and Agriculture Organization of the United Nations, Rome, $132 \mathrm{p}$.

[6] Schwartz, C., Fetzer, K.D., Kubiniok, J. and Morel, J.L. (2000) Availability of Pollutants in Garden Soils. Proceedings of the 1 st International Conference on Soils of Urban, Industrial, Traffic and Mining Areas (SUITMA), Essen, 12-18 July 2000, 485-490.

[7] Nowak, D.J., Crane, D.E. and Stevens, J.C. (2006) Air Pollution Removal by Urban Trees and Shrubs in the United States. Urban Forestry Urban Greening, 4, 115-123. https://doi.org/10.1016/j.ufug.2006.01.007

[8] Beckett, K., Freer-Smith, P. and Taylor, G. (2000) Effective Tree Species for Local Air Quality Management. Journal of Arboriculture, 26, 12-19.

[9] Kpangui, K.B. (2009) Contribution of Geographic Information Systems to the Study of the Specific Diversity of the Arboretum of the National Floristic Centre of the University of Cocody-Abidjan. Diplome d'Etudes Approfondies Thesis, Cocody-Abidjan University, Abidjan, $62 \mathrm{p}$.

[10] Reis, A.T., Coelho, J.P., Rodrigues, S.M., Rocha, R., Davidson, C.M., Duarte, A.C. and Pereira, E. (2012) Development and Validation of a Simple Thermo-Desorption Technique for Mercury Speciation in Soils and Sediments. Talanta, 99, 363-368. https://doi.org/10.1016/j.talanta.2012.05.065

[11] Bernhard-Reversat, F. (1972) Decomposition of Leaf Litter in the Lower Ivory Coast Rainforest. Oecology Plant, 7, 279-300.

[12] Oladoye, A.O., Ola-Adams, B.A. and Adedire, M.O. (2010) Litter Fall Dynamics in Leucaena leucocephala (Lam) de Wit plantation in the Nigerian Derived Savanna. Journal of Agriculture and Biological Sciences, 5, 31-38

[13] Oziegbe, M. and Faluyi, J.O. (2011) Reproductive Biology of Ludwigia leptocarpa and L. adscendens subsp. Diffusa in Ile-Ife, Nigeria. Turkish Journal of Botany, 36, 167-173.

[14] Isaac, M.E., Gordon, A.M., Thevathasan, N., Oppong, S.K. and Quashie Sam, S.J. (2005) Temporal Changes in Soil Carbon and Nitrogen in West African Multi-Strata Agroforestry Systems: A Chronosequence of Pools and Fluxes. Agroforestry Systems, 65, 23-31. https://doi.org/10.1007/s10457-004-4187-6

[15] Owusu-Sekyere, E., Cobbina, J. and Wakatsuki, T. (2006) Nutrient Cycling in Primary, Secondary Forests and Cocoa Plantations in the Ashanti Region, Ghana. West African Journal of Applied Ecology, 9, 10-19. https://doi.org/10.4314/wajae.v9i1.45680

[16] Dawoe, E.K., Isaac, M.E. and Quashie-Sam, J. (2010) Litter Fall and Litter Nutrient Dynamics under Cocoa Ecosystems in Lowland Humid Ghana. Plant and Soil, 330, 55-64. https://doi.org/10.1007/s11104-009-0173-0

[17] Pragasan, A. and Parthasarathy, N. (2005) Litter Production in Tropical Dry Evergreen Forests of South India in Relation to Season, Plant Life Forms and Physiognomic Groups. Current Science, 88, 1255-1263.

[18] Ndakara, O. (2012) Litter Fall and Nutriment Returns in Isolated Stards of Termilalia catappa Trees in the Rainforest Area of Southern Nigeria. Ethiopian Journal of Environmental Studies and Management, 5, $10 \mathrm{p}$. https://doi.org/10.4314/ejesm.v5i1.1

[19] Santa Regina, I. and Tarazona, T. (2001) Nutrient Pools to the Soil through Organic 
Matter and Throughfall under a Scots Pine Plantation in the Sierra de la Demanda, Spain. European Journal of Soil Biology, 37, 125-133.

https://doi.org/10.1016/S1164-5563(01)01072-X

[20] Yang, J., McBride, J., Zhou, J. and Sun, Z. (2005) The Urban Forest in Beijing and Its Role in Air Pollution Reduction. Urban Forestry \& Urban Greening, 3, 65-78. https://doi.org/10.1016/j.ufug.2004.09.001

[21] Wang, Q., Wang, S. and Huang, Y. (2008) Comparisons of Litter Fall, Litter Decomposition and Nutrient Return in a Monoculture Cunninghamia lanceolata and a Mixed Stand in Southern China. Forest Ecology Management, 255, 1210-1218. https://doi.org/10.1016/j.foreco.2007.10.026

[22] Leblond, S. (2004) Multidisciplinary Study of the Transfer of Metals from the Atmosphere to Mosses (Scleropodium purum (Hedw.) Limpr.): Monitoring on a $\mathrm{Ru}$ ral Site (Vouzon, France). PhD Thesis, Paris Diderot University, Paris, 224 p.

[23] Gandois, L. (2009) Dynamics and Balance of Trace Metal Elements (Heavy Metal) in Forest Ecosystems Français: Modelling, Specification and Critical Loads. PhD Thesis, Institut National Polytechnique de Toulouse, Toulouse, $318 \mathrm{p}$.

[24] Agnan, Y. (2013) Bioaccumulation and Bioindication by Lichens of Current and Past Air Pollution in Metals and Nitrogen in France: Sources, Mechanisms and Influencing Factors. PhD Thesis, University of Toulouse, Toulouse, 307 p.

[25] Moiseenko, T.I. (2017) Evolution of Biogeochemical Cycles under Anthropogenic Loads: Limits Impacts. Geochemistry International, 55, 841-860. https://doi.org/10.1134/S0016702917100081

[26] Papa, S., Bartoli, G., Pellegrino, A. and Fioretto, A. (2010) Microbial Activities and Trace Element Contents in an Urban Soil. Environmental Monitoring and Assessment, 165, 193-203. https://doi.org/10.1007/s10661-009-0938-1

[27] Pouyat, R.V. and McDonnell, M.J. (1991) Heavy Metal Accumulations in Forest Soils along an Urban-Rural Gradient in Southeastern New York, USA. Water, Air, Soil Pollution, 57, 797-807. https://doi.org/10.1007/BF00282943

[28] Bargagli, R. (1998) Trace Elements in Terrestrial Plants. An Ecophysiological Approach to Biomonitoring and Biorecovery. Springer, Berlin, $324 \mathrm{p}$.

[29] Pacyna, J.M., Pacyna, E.G. and Aas, W. (2009) Changes of Emissions and Atmospheric Deposition of Mercury, Lead, and Cadmium. Atmospheric Environment, 43, 117-127. https://doi.org/10.1016/j.atmosenv.2008.09.066

[30] Oga, M.S. (2008) Groundwater Resources in the Greater Abidjan Region (Côte d'Ivoire): Hydrochemical and Isotopic Approaches. PhD Thesis, Paris-Sud University, Orsay, $245 \mathrm{p}$.

[31] Mathieu, P. and Monnet, C. (1971) Physico-Chemistry of Rainwater in Savannah and Tropical Forests. Office de la Recherche Scientifique et Technique Outre-Mer, University of Nice Sophia Antipolis, Nice, 93-114.

[32] Cheret, V. (1987) La sapinière du Luchonnais (Pyrénées Hautes-Garonnaise): Phytoecological Study; Research on the Phenomenon of Forest Dieback. Doctoral Thesis, Université Toulouse III-Paul Sabatier, Toulouse, 287 p.

[33] Lefeivre, B. (1989) Chemical Composition and Acidity of Precipitation Collected in the Central Pyrenees: Relationship between Meteorological Situations and Acidification Processes. Diplôme d'Etudes Approfondies Thesis, Université Toulouse III-Paul Sabatier, Toulouse, $68 \mathrm{p}$.

[34] Gourlaouen, V. (1999) Study of pH Distribution in the Equatorial Atlantic Ocean: Application to the Modelling of Sound Propagation in the Ocean. Brest (FRA). DEA 
Thesis, Université de Bretagne Occidentale, Plouzané, 33 p.

[35] Prescott, C.E. (2002) The Influence of the Forest Canopy on Nutrient Cycling. Tree Physiology, 22, 1193-1200. https://doi.org/10.1093/treephys/22.15-16.1193

[36] Bolou-Bi, E.B., Vigier, N., Poszwa, A., Boudot, J.P. and Dambrine, E. (2012) Effects of Biogeochemical Processes on Magnesium Isotope Variations in a Forested Catchment in the Vosges Mountains (France). Geochimica et Cosmochimica Acta, 87, 341-355. https://doi.org/10.1016/j.gca.2012.04.005

[37] Probst, A., Fritz, B. and Viville, D. (1995) Mid-Term Trends in Acid Precipitation, Streamwater Chemistry and Element Budgets in the Strengbach Catchment (Vosges Mountains, France). Water Air and Soil Pollution, 79, 39-59.

https://doi.org/10.1007/BF01100429

[38] Augusto, L. (1999) Study of the Impact of Some Forest Species on the Biogeochemical Functioning and Vegetation of Acidic Soils. Doctoral Thesis, Henri Poincaré University, Nancy, $276 \mathrm{p}$.

[39] Bermudez, G.M.A., Jasan, R., Pla, R., Maria, L. and Pignata, M.L. (2012) Heavy Metals and Trace Lements in Atmospheric Fall-Out: Their Relationship with Topsoil and Wheat Element Composition. Journal of Hazardous Materials, 213-214, 447-456. https://doi.org/10.1016/j.jhazmat.2012.02.023

[40] Fortin, M.C., Bicudo, D.C., Bourotte, C., de Cicco, V. and Arcova, F.C.S. (2005) Rainfall and Throughfall Chemistry in the Atlantic Forest: A Comparison between Urban and Natural Sites (São Paulo State, Brazil). Hydrology and Earth System Sciences, 9, 570-585. https://doi.org/10.5194/hess-9-570-2005

[41] Rodrigo, A., Àvila, A. and Roda, F. (2003) The Chemistry of Precipitation, Throughfall and Stemflow in Two Holm Oak (Quercus ilex L.) Forests under a Contrasted Pollution Environment in NE Spain. The Science of the Total Environment, 305, 195-205. https://doi.org/10.1016/S0048-9697(02)00470-9

[42] Hou, H., Takamatsu, T., Koshikawa, M.K. and Hosomi, M. (2005) Trace Metals in Bulk Precipitation and Throughfall in a Suburban Area of Japan. Atmospheric Environment, 39, 3583-3595. https://doi.org/10.1016/j.atmosenv.2005.02.035

[43] Chiwa, M., Crossley, A., Sheppard, L.J., Sakugawa, H. and Cape, J.N. (2004) Throughfall Chemistry and Canopy Interactions in a Sitka Spruce Plantation Sprayed with Six Different Simulated Polluted Mist Treatments. Environmental Pollution, 127, 57-64. https://doi.org/10.1016/S0269-7491(03)00259-8

[44] Michalzik, B. and Stadler, B. (2005) Importance of Canopy Herbivores to Dissolved and Particulate Organic Matter Fluxes to the Forest Floor. Geoderma, 127, 227-236. https://doi.org/10.1016/j.geoderma.2004.12.006

[45] Avila, A. and Rodrigo, A. (2004) Trace Metal Fluxes in Bulk Deposition, Throughfall and Stemflow at Two Evergreen Oak Stands in NE Spain Subject to Different Exposure to the Industrial Environment. Atmospheric Environment, 38, 171-180. https://doi.org/10.1016/j.atmosenv.2003.09.067

[46] Gandois, L., Tipping, E., Dumat, C. and Probst, A. (2010) Canopy Influence on Trace Metal Atmospheric Inputs on Forest Ecosystems: Speciation in Throughfall. Atmospheric Environment, 44, 824-833. https://doi.org/10.1016/j.atmosenv.2009.11.028

[47] Mclellan, I., Hursthouse, A., Varela, A. and Pereira, C.S. (2013) Geochemical Approach to Assessing Human Impacts in Cork Oak Forest Soils of the MED Region. Journal of Geochemical Exploration, 132, 34-40. https://doi.org/10.1016/j.gexplo.2013.04.005 